\title{
Determinants of Vaccine Acceptance against COVID-19 in China: Perspectives on Knowledge and DrVac-COVID19S Scale
}

\author{
Chen Dong ${ }^{1,2,+}$, Qian Liang ${ }^{1,+}$, Tanao $\mathrm{Ji}^{3,+}{ }^{3}$, Jun Gu ${ }^{3}$, Jian Feng ${ }^{3}$, Min Shuai ${ }^{2}$, Xiaoming Zhang ${ }^{4}$, Rui Zhao ${ }^{1, *}$ \\ and Zhifeng $\mathrm{Gu}^{5, *}$ (i)
}

1 Research Center of Clinical Medicine, Affiliated Hospital of Nantong University, Nantong 226001, China; 2013510019@stmail.ntu.cn (C.D.); 2013310135@stmail.ntu.cn (Q.L.)

2 Department of Nursing, Affiliated Hospital of Nantong University, Nantong 226001, China; minshuai@ntu.edu.cn

3 Department of Respiratory, Affiliated Hospital of Nantong University, Nantong 226001, China; 2013300097@stmail.ntu.cn (T.J.); jungu@ntu.edu.cn (J.G.); jianfeng@ntu.edu.cn (J.F.)

4 Key Laboratory of Molecular Virology \& Immunology, Institut Pasteur of Shanghai, Chinese Academy of Sciences, Shanghai 200025, China; xmzhang@ips.ac.cn

5 Department of Rheumatology, Affiliated Hospital of Nantong University, Nantong 226001, China

* Correspondence: zrui@ntu.edu.cn (R.Z.); guzf@ntu.edu.cn (Z.G.); Tel.: +86-159-9650-5581 (R.Z.); +86-137-0629-1941 (Z.G.)

+ Chen Dong, Qian Liang and Tanao Ji contributed equally to this work contributed equally to this work.

check for updates

Citation: Dong, C.; Liang, Q.; Ji, T.; Gu, J.; Feng, J.; Shuai, M.; Zhang, X.; Zhao, R.; Gu, Z. Determinants of Vaccine Acceptance against COVID-19 in China: Perspectives on Knowledge and DrVac-COVID19S Scale. Int. J. Environ. Res. Public Health 2021, 18, 11192. https:// doi.org/10.3390/ijerph182111192

Academic Editor: Paul B. Tchounwou

Received: 6 September 2021

Accepted: 12 October 2021

Published: 25 October 2021

Publisher's Note: MDPI stays neutral with regard to jurisdictional claims in published maps and institutional affiliations.

Copyright: (c) 2021 by the authors. Licensee MDPI, Basel, Switzerland. This article is an open access article distributed under the terms and conditions of the Creative Commons Attribution (CC BY) license (https:// creativecommons.org/licenses/by/ $4.0 /)$.

\begin{abstract}
Background: This study determined the knowledge and attitudes regarding COVID-19 and assessed the acceptance of the COVID-19 vaccine among the Chinese population. Methods: An online and offline cross-sectional study was conducted from 1 to 18 June 2021 among the Chinese population. Demographic characteristics, attitudes, knowledge, values, impact, and autonomy regarding the COVID-19 vaccine were collected using questionnaire. The variables in our study were analyzed by Mann-Whitney test and chi-square test. Results: A total of $93.8 \%$ participants were willing to be vaccinated, $2.7 \%$ refused, and 3.5\% hesitated. In regards to knowledge about the COVID19 vaccine, $94.3 \%$ citizens surveyed knew about the spread of droplets and $65 \%$ had knowledge about surfaces touched by an infected person. In addition, $93.8 \%$ of participants had knowledge of the common symptoms related to COVID-19, such as fever and cough (93.8\%), shortness of breath/anorexia/fatigue/nausea/vomiting/diarrhea (80.2\%), and panic and chest tightness (69.4\%). Most participants had a strong self-prevention awareness, such as washing hands regularly (92.1\%) and wearing a facemask (94.1\%). Besides, over ninety percent of respondents would report exposure to SARS-CoV-2 (96.6\%) and exposure to symptoms possibility related to COVID-19 (92.9\%). If necessary, most respondents would agree to isolate at home (93.5\%) or an isolation in hospital (96.3\%). Knowledge of COVID-19, including transmission, symptoms, protective measures, and vaccines itself, is associated with vaccination attitude. Values, perceived impacts, knowledge, and autonomy, assessed by the scale of DrVac-COVID19S, have also been revealed as important determinants to vaccine acceptance. Conclusions: Almost $93 \%$ of Chinese people surveyed in this study showed a willing attitude toward COVID-19 vaccination. Based on the above results, government and social workers can take measures from these perspectives to improve the vaccination attitude, so as to increase vaccine immunization rates.
\end{abstract}

Keywords: COVID-19; SARS-CoV-2; vaccine; acceptance; knowledge; attitude

\section{Introduction}

The ongoing Coronavirus Disease 2019 (COVID-19) pandemic in 2019 has become a major global health threat, with more than 208 million cases and nearly 4 million deaths worldwide (data from the World Health Organization). COVID-19 is caused by the novel severe acute respiratory syndrome coronavirus 2 (SARS-CoV-2), which leads to series of 
symptoms, including fever, dry cough, short of breath and multiple organs and systems disfunction [1]. COVID-19 can cause not only high mortality and morbidity, but also serious effects on anxiety, depression, social distance, social burden, and economic development [2].

To date, there is no effective therapy for COVID-19. Therefore, the key management of COVID-19 pandemic is the availability of effective vaccines, which helps reduce transmission, hospitalization, and the need for intensive care [3]. It has been estimated that the basic reproductive number for SARS-CoV-2 was at 2.4-3.4, so that only large-scale, equitable access and distribution of a COVID-19 vaccine can achieve herd immunity against SARS$\mathrm{CoV}-2$, and uptake of vaccine should reach 60-72\% [4]. However, successful vaccination programs are largely affected by acceptance rates, which are not satisfactory on a global scale [5]. A global survey showed that potential acceptance of the COVID-19 vaccine across countries and regions varies from $27.3 \%$ to $88.6 \%$ [6]. One of biggest barriers to full population inoculation against COVID-19 is vaccine hesitancy.

In 2015, the WHO Strategic Advisory Group of Experts on Immunization defined vaccine hesitancy as a "delay in acceptance or refusal of vaccination despite availability of vaccination service" [7]. The vaccine hesitancy of COVID-19 is increasing globally [8]. When a new vaccine is introduced, vaccine hesitancy occurs and is influenced by many factors $[9,10]$. These include the environmental factors, host factors, and agents factors, such as safety and effectiveness of vaccines, adverse health outcomes, misunderstandings about the necessity of vaccination, lack of trust in the health system, and lack of community understanding of vaccine-preventable diseases [11,12]. Therefore, studying the determinants of COVID-19 vaccine hesitancy can help in guiding interventional measures aimed at building and maintaining responses to enhance trust in, and acceptance of, the vaccine and those who deliver it.

In China, Hai Fang et al. reported that $91.3 \%$ of Chinese people would accept COVID19 and $52.2 \%$ persons wanted to get vaccinated as quickly as possible after the vaccine became available in March 2020 [13]. In June 2020, acceptance rates of COVID-19 vaccines ranged up to $90 \%$ in China [6]. Moreover, the Chinese version Drivers of COVID-19 Vaccination Acceptance Scale (DrVac-COVID19S) has been used to assess the values, impacts, knowledge, and autonomy since March 2021, and the scale deeply enhances the interpretability of research results [14]. More importantly, China is a huge, diverse country, so more research about the acceptance and delineation of demographics related to COVID-19 vaccines in China would be helpful and can provide a theoretical basis for the global epidemic management. In the present study, we conducted a survey to assess the public attitude to COVID-19 vaccination and explore contributing factors of COVID19 vaccination attitude, so as to provide a theoretical basis and intervention directions for healthcare providers and policymakers and improve the vaccination rate and finally achieve effective epidemic management.

\section{Methodology}

\subsection{Participants}

This cross-sectional study was conducted in China during June 2021. Firstly, participants were recruited online via snowball sampling (a type of convenience sampling) using the software of Wen Juan Xing (Changsha Ranxing Information Technology Co., Ltd., Changsha City, China). The software, similar to Qualtrics, SurveyMonkey, or CloudResearch, can provide online questionnaire design and survey functions and is the largest online survey platform in China allowing for an authentic, diverse, and representative sample. Secondly, in order to reduce selection bias of missing samples based on old age, lower income, rural, no internet, etc., an offline survey was also conducted in villages in Nantong City, Jiangsu Province, China. Based on the exclusion criteria of participants under the age of 18, the final sample consisted of 1910 individuals. 


\subsection{Self-Reported Questionnaires}

Demographic variables were the following: gender, age, place of residence, marital status, education, income/year, use tobacco or alcohol, health status, live alone or not, have children in home or not.

A knowledge questionnaire regarding the spread, common symptoms, and protective measures of COVID-19 was designed referring to China's national conditions and existing research, especially Abdelhafiz AS's reports [15].

The Drivers of COVID-19 Vaccination Acceptance Scale (DrVac-COVID19S) was also conducted in this study, which is an instrument assessing attitudes and considerations in COVID-19 vaccines [14]. A higher score in DrVac-COVID19S indicates higher level of COVID-19 vaccine acceptance. The scale contains four dimensions of values, impacts, knowledge, and autonomy, revealing the underlying mechanism of different attitudes to COVID-19 vaccination.

\subsection{Data Analysis}

The variables in our study all involved abnormal distribution data, which were demonstrated in median (IQR) and analyzed by Mann-Whitney test. Descriptive statistics also involved frequencies (\%) for categorical variables and group differences were assessed using the chi-square test. Statistical significance was considered when $p<0.05$ (two-sided). All analyses were performed using SPSS version 21.0.

\section{Results}

\subsection{Participant Characteristics}

In this study, we recruited 1910 citizens in China and assessed their attitudes about COVID-19 vaccines, socioeconomic status, knowledge about COVID-19 (including spread ways, common symptoms, prevention measures), and knowledge about COVID-19 vaccines. In the present study, $93.8 \%$ participants were willing to be vaccinated, $2.7 \%$ refused, and $3.5 \%$ hesitated. Age, place of residence, marital status, educational level, income, and health status showed a significant association with acceptance. Overall, the majority of participants surveyed were positive about COVID-19 vaccination.

\subsection{Differences between Willing/Unwilling/Hesitant Attitudes in Relation to Socioeconomic Items}

Among all the participants, citizens aged over 50 years old showed higher refusal of vaccines when compared with young adults. In total, 118/1910 persons were skeptical of being vaccinated and nearly forty percent of people over 60-years-old refused or hesitated to get the vaccine. Participants with low incomes and chronic disease were more likely to refuse to be vaccinated. Interestingly, individuals with lower education were the largest group who refused to get vaccinated, while the biggest survey group hesitating to get vaccinated was actually the highly educated crowd. Participants with a primary school educational level were most likely to refuse vaccination, followed by individuals with junior middle school education. Moreover, participants with university educational experience were mostly likely to hesitate regarding COVID-19 vaccination and individuals with higher educational level of high school showed more possibility of hesitation (Figure 1). In addition, smokers or non-smokers and drinkers or non-drinkers showed no significant statistical differences in attitudes of willingness or refusal/hesitation, but the number of drinkers and smokers was relatively fewer than non-drinkers and non-smokers in this study, indicating the importance of relevant further study. (Table 1). 


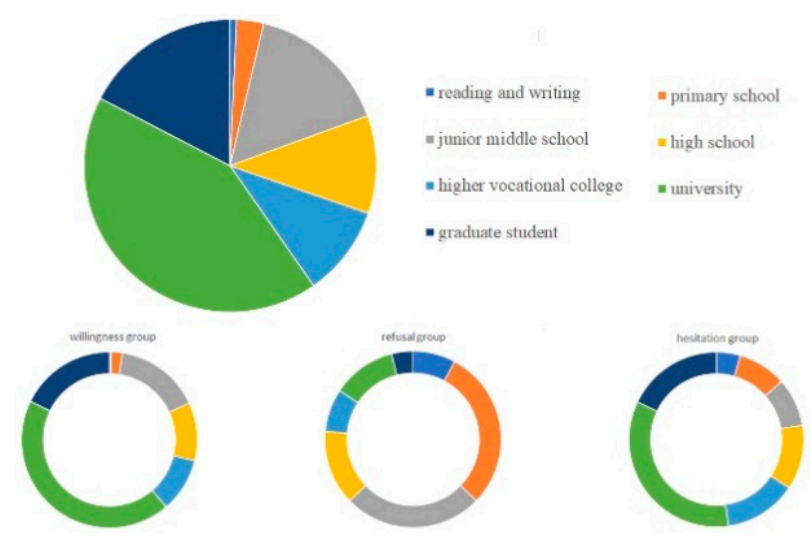

Figure 1. Pie charts of educational level in different attitude groups of COVID-19 vaccines.

Table 1. The differences between willing, unwilling, and hesitant attitudes in relation to socioeconomic items.

\begin{tabular}{|c|c|c|c|c|c|}
\hline \multirow[b]{2}{*}{ Items } & \multirow[b]{2}{*}{ All } & \multicolumn{3}{|c|}{ Attitude of Being Vaccinated } & \multirow{2}{*}{$p$} \\
\hline & & Willingness & Refusal & Hesitation & \\
\hline Attitude of vaccination & $1910(100)$ & $1792(93.8)$ & $51(2.7)$ & $67(3.5)$ & - \\
\hline \multicolumn{5}{|l|}{ Age, years } & \multirow[t]{6}{*}{$<0.001$} \\
\hline $18-<30$ & $423(22.1)$ & 407 (22.7) & $6(11.8)$ & $10(14.9)$ & \\
\hline $30-<40$ & $598(31.3)$ & $576(32.1)$ & $6(11.8)$ & $16(23.9)$ & \\
\hline $40-<50$ & $535(28)$ & $510(28.5)$ & $8(15.7)$ & $17(25.4)$ & \\
\hline $50-<60$ & $271(14.2)$ & 249 (13.9) & $10(19.6)$ & 12 (17.9) & \\
\hline$\geq 60$ & $83(4.3)$ & $50(2.8)$ & $21(41.2)$ & $12(17.9)$ & \\
\hline \multicolumn{5}{|l|}{ Gēnder } & \multirow[t]{3}{*}{0.955} \\
\hline male & $713(37.3)$ & $670(37.4)$ & $18(35.3)$ & $25(37.3)$ & \\
\hline female & 1199 (62.7) & $1122(62.6)$ & $33(64.7)$ & $42(62.7)$ & \\
\hline & \multirow[t]{3}{*}{$<0.001$} \\
\hline urban & 1503 (78.7) & $1423(79.4)$ & $27(52.9)$ & $53(79.1)$ & \\
\hline Rural & 407 (21.3) & $369(20.6)$ & $24(47.1)$ & $14(20.9)$ & \\
\hline \multicolumn{5}{|l|}{ Marital status } & \multirow[t]{3}{*}{0.026} \\
\hline married & $1550(81.2)$ & $1444(80.6)$ & $48(94.1)$ & $58(86.6)$ & \\
\hline others & $360(18.8)$ & $348(19.4)$ & $3(5.9)$ & $9(13.4)$ & \\
\hline \multicolumn{5}{|l|}{ Educational level } & \multirow[t]{8}{*}{$<0.001$} \\
\hline reading and writing & $14(0.7)$ & $7(0.4)$ & $4(7.8)$ & $3(4.5)$ & \\
\hline primary school & $57(3)$ & $36(2)$ & $15(29.4)$ & $6(9)$ & \\
\hline junior middle school & $301(15.8)$ & $282(15.7)$ & $13(25.5)$ & $6(9)$ & \\
\hline high school & $206(10.8)$ & $191(10.7)$ & $7(13.7)$ & $8(11.9)$ & \\
\hline higher vocational college & $192(10)$ & $179(10)$ & $4(7.8)$ & $9(13.4)$ & \\
\hline university & $808(42.3)$ & 779 (43.5) & $6(11.8)$ & $23(34.3)$ & \\
\hline graduate student & $332(17.4)$ & $318(17.7)$ & $2(3.9)$ & 12 (17.9) & \\
\hline \multicolumn{5}{|l|}{ Yearly per capita income, RMB } & \multirow[t]{4}{*}{$<0.001$} \\
\hline$<50,000$ & $468(24.5)$ & $413(23.1)$ & $34(66.7)$ & $21(31.3)$ & \\
\hline $50,000-100,000$ & $658(34.5)$ & $624(34.8)$ & $12(23.5)$ & $22(32.8)$ & \\
\hline$>100,000$ & $784(41)$ & $755(42.1)$ & $5(9.8)$ & $24(35.8)$ & \\
\hline \multicolumn{5}{|l|}{ Tobacco use } & \multirow[t]{3}{*}{0.940} \\
\hline yes & $208(10.9)$ & $194(10.8)$ & $6(11.8)$ & $8(11.9)$ & \\
\hline no & $1702(89.1)$ & $1598(89.2)$ & $45(88.2)$ & $59(88.1)$ & \\
\hline \multicolumn{5}{|l|}{ Alcohol use } & \multirow[t]{3}{*}{0.532} \\
\hline yes & $104(5.4)$ & $99(5.5)$ & $1(2)$ & $4(6)$ & \\
\hline no & $1806(94.6)$ & $1693(94.5)$ & $50(98)$ & $63(94)$ & \\
\hline \multicolumn{5}{|l|}{ Health status } & \multirow[t]{3}{*}{$<0.001$} \\
\hline health & 1647 (86.2) & $1596(89.1)$ & $11(21.6)$ & $40(59.7)$ & \\
\hline chronic disease & $263(13.8)$ & $196(10.9)$ & $40(78.4)$ & $27(40.3)$ & \\
\hline \multicolumn{5}{|l|}{ Living alone } & \multirow[t]{3}{*}{0.756} \\
\hline yes & $126(6.6)$ & $120(6.7)$ & $3(5.9)$ & $3(4.5)$ & \\
\hline no & $1784(93.4)$ & 1672 (93.3) & $48(94.1)$ & $64(95.5)$ & \\
\hline Have children at home & & & & & 0.324 \\
\hline yes & $1573(82.4)$ & $1476(82.4)$ & $45(88.2)$ & $52(77.6)$ & \\
\hline no & 337 (17.6) & $316(17.6)$ & $6(11.8)$ & $15(22.4)$ & \\
\hline
\end{tabular}




\subsection{Differences between Willing/Unwilling/Hesitant Attitudes in Relation to Knowledge of COVID-19}

Most participants were aware of the main ways SARS-CoV-2 spreads. As shown in Table 2, a total of $94.3 \%$ citizens knew about the spread of droplets from an infected person and $65 \%$ knew about surfaces touched by an infected person. Among the participants who refused to be vaccinated, $37.3 \%$ citizens did not know about the spread of droplets from infected people and $72.5 \%$ did not realize it could spread via surfaces touched by an infected person. Among participants who refused, $80.4 \%$ did not know about the transmission aerosols, while $88.2 \%$ of them did not know about transmission through food and water, same as oral-fecal transmission.

Table 2. The differences between willing, unwilling, and hesitant attitudes in relation to knowledge of COVID-19.

\begin{tabular}{|c|c|c|c|c|c|}
\hline \multirow[b]{2}{*}{ Items } & \multirow{2}{*}{ All } & \multicolumn{3}{|c|}{ Attitude of Being Vaccinated } & \multirow{2}{*}{$p$} \\
\hline & & Willingness & Refusal & Hesitation & \\
\hline \multicolumn{6}{|l|}{ COVID-19 spreads by } \\
\hline \multirow{3}{*}{$\begin{array}{l}\text { 1. Droplets of affected person (with cough or expiration) } \\
\text { yes } \\
\text { no }\end{array}$} & & & & & $<0.001$ \\
\hline & $1802(94.3)$ & $1711(95.5)$ & $32(62.7)$ & $59(88.1)$ & \\
\hline & $108(5.7)$ & $81(4.5)$ & $19(37.3)$ & $8(11.9)$ & \\
\hline \multicolumn{2}{|l|}{ 2. Surfaces touched by affected person } & & & & $<0.001$ \\
\hline yes & $1242(65)$ & $1193(66.6)$ & $14(27.5)$ & $35(52.2)$ & \\
\hline no & $668(35)$ & $599(33.4)$ & $37(72.5)$ & $32(47.8)$ & \\
\hline \multicolumn{2}{|l|}{ 3. Aerosol transmission } & & & & $<0.001$ \\
\hline yes & $1150(60.2)$ & $1113(62.1)$ & $10(19.6)$ & $27(40.3)$ & \\
\hline no & $760(39.8)$ & $679(37.9)$ & $41(80.4)$ & $40(59.7)$ & \\
\hline \multicolumn{2}{|l|}{ 4.Transmission through food and water } & & & & $<0.001$ \\
\hline yes & $858(44.9)$ & $828(46.2)$ & $6(11.8)$ & $24(35.8)$ & \\
\hline no & $1052(55.1)$ & $964(53.8)$ & $45(88.2)$ & $43(64.2)$ & \\
\hline \multicolumn{2}{|l|}{ 5. Oral-fecal transmission } & & & & $<0.001$ \\
\hline yes & $832(43.6)$ & $806(45.0)$ & $6(11.8)$ & $20(29.9)$ & \\
\hline no & $1078(56.4)$ & $986(55.0)$ & $45(88.2)$ & $47(70.1)$ & \\
\hline \multicolumn{6}{|l|}{ Common symptoms include } \\
\hline \multicolumn{2}{|l|}{ 1. Fever and cough } & & & & $<0.001$ \\
\hline yes & $1792(93.8)$ & $1706(95.2)$ & $30(58.8)$ & $56(83.6)$ & \\
\hline no & $118(6.2)$ & $86(4.8)$ & $21(41.2)$ & $11(16.4)$ & \\
\hline \multicolumn{2}{|l|}{$\begin{array}{l}\text { 2. Shortness of breath, anorexia, fatigue, nausea, vomiting, } \\
\text { diarrhea }\end{array}$} & & & & $<0.001$ \\
\hline yes & $1532(80.2)$ & $1478(82.5)$ & $12(23.5)$ & $42(62.7)$ & \\
\hline no & $378(19.8)$ & $314(17.5)$ & $39(76.5)$ & $25(37.3)$ & \\
\hline \multicolumn{2}{|l|}{ 3. Panic and chest tightness } & & & & $<0.001$ \\
\hline yes & $1325(69.4)$ & $1284(71.7)$ & 7 (13.7) & $34(50.7)$ & \\
\hline no & $585(30.6)$ & $508(28.3)$ & $44(86.3)$ & $33(49.3)$ & \\
\hline \multicolumn{2}{|l|}{ 4. Body aches } & & & & $<0.001$ \\
\hline yes & $1247(65.3)$ & $1213(67.7)$ & $6(11.8)$ & $28(41.8)$ & \\
\hline no & $663(34.7)$ & $579(32.3)$ & $45(88.2)$ & $39(58.2)$ & \\
\hline \multicolumn{2}{|l|}{ 5. Conjunctival congestion } & & & & $<0.001$ \\
\hline yes & $675(35.3)$ & $656(36.6)$ & $5(9.8)$ & $14(20.9)$ & \\
\hline no & $1235(64.7)$ & $1136(63.4)$ & $46(90.2)$ & $53(79.1)$ & \\
\hline
\end{tabular}

In addition, $93.8 \%$ participants had knowledge of common symptoms related to COVID-19, such as fever and cough (93.8\%), shortness of breath/anorexia/fatigue/nausea/ vomiting/diarrhea (80.2\%), and panic and chest tightness (69.4\%). Among the participants who were willing to be vaccinated, $95.2 \%$ knew the symptoms of fever and cough and $82.5 \%$ were aware of shortness of breath/anorexia/fatigue/nausea/vomiting/diarrhea, while $71.7 \%$ knew about panic and chest tightness and $67.7 \%$ knew about body aches. Nevertheless, many citizens lacked awareness of SARS-CoV-2 transmission, including via polluted food/water, oral-fecal transmission, and the conjunctival congestion of COVID-19 symptoms. All the above are shown in Table 2. 


\subsection{Differences between Willing/Unwilling/Hesitant Attitudes in Relation to Preventive Measures/Behaviors of COVID-19}

Daily behaviors related to COVID-19 prevention also were assessed in this study (Table 3). Among Chinese citizens, $92.1 \%$ of them washed hands regularly and $94.1 \%$ of them usually wore a facemask. In addition, $96.6 \%$ of participants would report exposure to SARS-CoV-2 and $92.9 \%$ of participants would actively report the exposure of symptoms possibility related to COVID-19. If necessary, $93.5 \%$ persons would agree to isolate at home and $96.3 \%$ would agree to be isolated at an isolation hospital. A total of $91.8 \%$ of Chinese participants were concerned about the latest news about the spread of the COVID-19 in China, and $89.8 \%$ of Chinese people were concerned about the global epidemic. Meanwhile, $92.5 \%$ participants would get the knowledge and follow the instruction if it was available. It indicates that Chinese pay attention to the COVID-19 epidemic and are in a good selfmanagement state, which have become the necessary factors for the country to achieve effective epidemic control. All the above are shown in Table 3 and Table S1.

Table 3. The differences between willing, unwilling, and hesitant attitudes in relation to preventive measures of COVID-19.

\begin{tabular}{|c|c|c|c|c|c|}
\hline \multirow{2}{*}{ Items } & \multirow{2}{*}{ All } & \multicolumn{3}{|c|}{ Attitude of Being Vaccinated } & \multirow[b]{2}{*}{$p$} \\
\hline & & Willingness & Refusal & Hesitation & \\
\hline $\begin{array}{l}\text { 1. When I meet my friends and colleagues, I will always greet } \\
\text { them with a handshake }\end{array}$ & & & & & 0.017 \\
\hline agree & $422(22.1)$ & $410(22.9)$ & $3(5.9)$ & $9(13.4)$ & \\
\hline uncertain & $508(26.6)$ & $473(26.4)$ & $14(27.5)$ & $21(31.3)$ & \\
\hline disagree & $980(51.3)$ & $909(50.7)$ & $34(66.7)$ & $37(55.2)$ & \\
\hline $\begin{array}{l}\text { 2. When I meet my friends and colleagues, I will always greet } \\
\text { them with a hug }\end{array}$ & & & & & 0.280 \\
\hline agree & $181(9.5)$ & $176(9.8)$ & $2(3.9)$ & $3(4.5)$ & \\
\hline uncertain & $414(21.7)$ & $390(21.8)$ & $12(23.5)$ & $12(17.9)$ & \\
\hline disagree & $1315(68.8)$ & $1226(68.4)$ & $37(72.5)$ & $52(77.6)$ & \\
\hline 3. I wash my hands regularly and for enough period of time & & & & & $<0.001$ \\
\hline agree & $1760(92.1)$ & $1702(95)$ & $13(25.5)$ & $45(67.2)$ & \\
\hline uncertain & $84(4.4)$ & $63(3.5)$ & $13(25.5)$ & $8(11.9)$ & \\
\hline disagree & $66(3.5)$ & $27(1.5)$ & $25(49)$ & $14(20.9)$ & \\
\hline $\begin{array}{l}\text { 4. I usually put a facemask to protect myself from the risk of } \\
\text { infection }\end{array}$ & & & & & $<0.001$ \\
\hline agree & $1798(94.1)$ & $1695(94.6)$ & $40(78.4)$ & $63(94)$ & \\
\hline uncertain & $88(4.6)$ & $79(4.4)$ & $5(9.8)$ & $4(6)$ & \\
\hline disagree & $24(1.3)$ & $18(1.0)$ & $6(11.8)$ & $0(0)$ & \\
\hline $\begin{array}{l}\text { 5. If I find that I contacted a person infected with the virus, I will } \\
\text { inform the health authorities }\end{array}$ & & & & & $<0.001$ \\
\hline agree & $1846(96.6)$ & $1756(98.0)$ & $33(64.7)$ & $57(85.1)$ & \\
\hline uncertain & $48(2.5)$ & $27(1.5)$ & $13(25.5)$ & $8(11.9)$ & \\
\hline disagree & $16(0.8)$ & $9(0.5)$ & $5(9.8)$ & $2(3)$ & \\
\hline $\begin{array}{l}\text { 6. If I have any of the symptoms associated with the disease, I } \\
\text { will inform the health authorities }\end{array}$ & & & & & $<0.001$ \\
\hline agree & $1775(92.9)$ & $1691(94.4)$ & $31(60.8)$ & $53(79.1)$ & \\
\hline uncertain & $108(5.7)$ & $81(4.5)$ & $15(29.4)$ & $12(17.9)$ & \\
\hline disagree & $27(1.4)$ & $20(1.1)$ & $5(9.8)$ & $2(3)$ & \\
\hline $\begin{array}{l}\text { 7. If I find that I contacted a person infected with the virus, I } \\
\text { agree to be isolated at home for a certain period of time until it is } \\
\text { proven that I am free from the disease }\end{array}$ & & & & & $<0.001$ \\
\hline agree & $1786(93.5)$ & $1686(94.1)$ & $41(80.4)$ & $59(88.1)$ & \\
\hline uncertain & $51(2.7)$ & $41(2.3)$ & $4(7.8)$ & $6(9)$ & \\
\hline disagree & $73(3.8)$ & $65(3.6)$ & $6(11.8)$ & $2(3)$ & \\
\hline
\end{tabular}


Table 3. Cont.

\begin{tabular}{|c|c|c|c|c|c|}
\hline \multirow[b]{2}{*}{ Items } & \multirow[b]{2}{*}{ All } & \multicolumn{3}{|c|}{ Attitude of Being Vaccinated } & \multirow[b]{2}{*}{$p$} \\
\hline & & Willingness & Refusal & Hesitation & \\
\hline $\begin{array}{l}\text { 8. If I found that I contacted a person infected with the virus, I } \\
\text { agree to be isolated at an isolation hospital for a certain period of } \\
\text { time until it is proven that I am free from the disease }\end{array}$ & & & & & $<0.001$ \\
\hline agree & $1839(96.3)$ & $1742(97.2)$ & $41(80.4)$ & $56(83.6)$ & \\
\hline uncertain & $55(2.9)$ & $40(2.2)$ & $5(9.8)$ & $10(14.9)$ & \\
\hline disagree & $16(0.8)$ & $10(0.6)$ & $5(9.8)$ & $1(1.5)$ & \\
\hline $\begin{array}{l}\text { 9. If I am asked to be isolated for a certain period of time, I think } \\
\text { my salary will continue during this period }\end{array}$ & & & & & 0.171 \\
\hline agree & $1139(59.6)$ & $1071(59.8)$ & $30(58.8)$ & $38(56.7)$ & \\
\hline uncertain & $429(22.5)$ & $409(22.8)$ & $7(13.7)$ & $13(19.4)$ & \\
\hline disagree & $342(17.9)$ & $312(17.4)$ & $14(27.5)$ & $16(23.9)$ & \\
\hline $\begin{array}{l}\text { 10. If I am asked to be isolated for a certain period of time, my } \\
\text { salary should be continued during this period }\end{array}$ & & & & & 0.311 \\
\hline agree & $1389(72.8)$ & $1299(72.5)$ & $43(84.3)$ & $47(70.1)$ & \\
\hline uncertain & $339(17.7)$ & $319(17.8)$ & $7(13.7)$ & $13(19.4)$ & \\
\hline disagree & $182(9.5)$ & $174(9.7)$ & $1(2)$ & $7(10.4)$ & \\
\hline $\begin{array}{l}\text { 11. If there is an available lab test for detection of the virus, I am } \\
\text { willing to do it }\end{array}$ & & & & & $<0.001$ \\
\hline agree & 1865 (97.6) & $1756(98)$ & $48(94.1)$ & $61(91)$ & \\
\hline uncertain & $40(2.1)$ & $31(1.7)$ & $3(5.9)$ & $6(9)$ & \\
\hline disagree & $5(0.3)$ & $5(0.3)$ & $0(0)$ & $0(0)$ & \\
\hline $\begin{array}{l}\text { 12. If there is an available vaccine for the virus, I am willing to get } \\
\text { it }\end{array}$ & & & & & $<0.001$ \\
\hline agree & $1773(92.8)$ & $1740(97.1)$ & $10(19.6)$ & $23(34.3)$ & \\
\hline uncertain & $76(4)$ & $43(2.4)$ & $4(7.8)$ & $29(43.3)$ & \\
\hline disagree & $61(3.2)$ & $9(0.5)$ & $37(72.5)$ & $15(22.4)$ & \\
\hline $\begin{array}{l}\text { 13. I usually follow the updates about the spread of the virus in } \\
\text { my country }\end{array}$ & & & & & $<0.001$ \\
\hline agree & $1753(91.8)$ & $1693(94.5)$ & $16(31.4)$ & $44(65.7)$ & \\
\hline uncertain & $116(6.1)$ & $81(4.5)$ & $20(39.2)$ & $15(22.4)$ & \\
\hline disagree & $41(2.1)$ & $18(1)$ & $15(29.4)$ & $8(11.9)$ & \\
\hline $\begin{array}{l}\text { 14. I usually follow the updates about the spread of the virus } \\
\text { worldwide }\end{array}$ & & & & & $<0.001$ \\
\hline agree & $1715(89.8)$ & $1658(92.5)$ & $14(27.5)$ & $43(64.2)$ & \\
\hline uncertain & $149(7.8)$ & $110(6.1)$ & $22(43.1)$ & $17(25.4)$ & \\
\hline disagree & $46(2.4)$ & $24(1.3)$ & $15(29.4)$ & $7(10.4)$ & \\
\hline $\begin{array}{l}\text { 15. If a lecture about the virus is organized near me, I will attend } \\
\text { it }\end{array}$ & & & & & $<0.001$ \\
\hline agree & $1317(69)$ & $1280(71.4)$ & $10(19.6)$ & $27(40.3)$ & \\
\hline uncertain & $526(27.5)$ & $459(25.6)$ & $32(62.7)$ & $35(52.2)$ & \\
\hline disagree & $67(3.5)$ & $53(3)$ & $9(17.6)$ & $5(7.5)$ & \\
\hline $\begin{array}{l}\text { 16. If flyers or brochures that include information about the } \\
\text { disease are distributed, I will read them and follow the } \\
\text { instructions mentioned in them }\end{array}$ & & & & & $<0.001$ \\
\hline agree & $1767(92.5)$ & $1693(94.5)$ & $23(45.1)$ & $51(76.1)$ & \\
\hline uncertain & $117(6.1)$ & $82(4.6)$ & $21(41.2)$ & $14(20.9)$ & \\
\hline disagree & $26(1.4)$ & $17(0.9)$ & $7(13.7)$ & $2(3)$ & \\
\hline
\end{tabular}

\subsection{Differences between Willing/Unwilling/Hesitant Attitudes in Relation to Knowledge of} COVID-19 Vaccination

As shown in Table 4 and Table S2, the scale of DrVac-COVID19S was used in this study to assess the knowledge of vaccination. All the participants achieved the overall score of 68 (62.76) and the score of the willing group was to 69 (63.77). Participants with hesitant attitudes showed the lowest score of 55 (49.62), followed by the group who refused with 57 (49.63). The four dimensions of DrVac-COVID19S, including value, impacts, knowledge, and autonomy were all key traits for participants to decide to be vaccinated or not. The 
scores of the four dimensions were all higher among participants who will to be vaccinated than those who refused or hesitated. Moreover, each item of DrVac-COVID19S shows the statistical difference among three groups, including the items assessing vaccine efficacy, importance, autonomous choice, and mechanisms of the vaccine.

Table 4. The differences between willing, unwilling, and hesitant attitudes in relation to knowledge of COVID-19 vaccination.

\begin{tabular}{|c|c|c|c|c|c|}
\hline \multirow{2}{*}{ Items } & \multirow{2}{*}{ All } & \multicolumn{3}{|c|}{ Attitude of Being Vaccinated } & \multirow{2}{*}{$p$} \\
\hline & & Willingness & Refusal & Hesitation & \\
\hline Total score of DrVac-COVID19S & $68(62.76)$ & $69(63.77)$ & $57(49.63)$ & $55(49.62)$ & $<0.001$ \\
\hline value & $18(17.21)$ & 19 (18.21) & $16(12.18)$ & 15 (13.18) & $<0.001$ \\
\hline impacts & $16(14.19)$ & 17 (14.19) & 15 (12.18) & 14 (12.17) & $<0.001$ \\
\hline knowledge & $16(14.19)$ & $16(14.19)$ & $9(7.11)$ & $11(9.13)$ & $<0.001$ \\
\hline autonomy traits & $18(15.20)$ & $18(15.20)$ & $18(16.18)$ & $14(12.17)$ & $<0.001$ \\
\hline $\begin{array}{l}\text { 1. Vaccination is a very effective way to protect me against } \\
\text { COVID-19. }\end{array}$ & & & & & $<0.001$ \\
\hline agree & $1494(78.2)$ & $1430(79.8)$ & $30(58.8)$ & $34(50.7)$ & \\
\hline uncertain & $305(16)$ & $261(14.6)$ & $18(35.3)$ & $26(38.8)$ & \\
\hline disagree & $111(5.8)$ & $101(5.6)$ & $3(5.9)$ & $7(10.4)$ & \\
\hline 2. I know very well how vaccination protects me from COVID-19. & & & & & $<0.001$ \\
\hline agree & 1401 (73.4) & 1378 (76.9) & $6(11.8)$ & $17(25.4)$ & \\
\hline uncertain & $337(17.6)$ & $310(17.3)$ & $4(7.8)$ & $23(34.3)$ & \\
\hline disagree & $172(9)$ & $104(5.8)$ & $41(80.4)$ & $27(40.3)$ & \\
\hline 3. It is important that I get the COVID-19 jab. & & & & & $<0.001$ \\
\hline agree & $1811(94.8)$ & $1726(96.3)$ & $36(70.6)$ & $49(73.1)$ & \\
\hline uncertain & $75(3.9)$ & $49(2.7)$ & $13(25.5)$ & $13(19.4)$ & \\
\hline disagree & $24(1.3)$ & $17(0.9)$ & $2(3.9)$ & $5(7.5)$ & \\
\hline 4. Vaccination greatly reduces my risk of catching COVID-19. & & & & & $<0.001$ \\
\hline agree & $1757(92)$ & 1675 (93.5) & 35 (68.6) & $47(70.1)$ & \\
\hline uncertain & $128(6.7)$ & $100(5.6)$ & $14(27.5)$ & $14(20.9)$ & \\
\hline disagree & $25(1.3)$ & $17(0.9)$ & $2(3.9)$ & $6(9)$ & \\
\hline 5. I understand how the flu jab helps my body fight the & & & & & $<0.001$ \\
\hline agree & $1534(80.3)$ & $1465(81.8)$ & $30(58.8)$ & $39(58.2)$ & \\
\hline uncertain & $315(16.5)$ & $280(15.6)$ & $15(29.4)$ & $20(29.9)$ & \\
\hline disagree & $61(3.2)$ & $47(2.6)$ & $6(11.8)$ & $8(11.9)$ & \\
\hline $\begin{array}{l}\text { 6. The COVID- } 19 \text { jab plays an important role in protecting my life } \\
\text { and that of others. }\end{array}$ & & & & & $<0.001$ \\
\hline agree & $1727(90.4)$ & $1649(92)$ & $33(64.7)$ & $45(67.2)$ & \\
\hline uncertain & $147(7.7)$ & $112(6.2)$ & $16(31.4)$ & $19(28.4)$ & \\
\hline disagree & $36(1.9)$ & $31(1.7)$ & $2(3.9)$ & $3(4.5)$ & \\
\hline 7. I feel under pressure to get the COVID-19 jab. & & & & & $<0.001$ \\
\hline agree & $267(14)$ & $243(13.6)$ & $6(11.8)$ & $18(26.9)$ & \\
\hline uncertain & $206(10.8)$ & $183(10.2)$ & $6(11.8)$ & $17(25.4)$ & \\
\hline disagree & $1437(75.2)$ & $1366(76.2)$ & $39(76.5)$ & $32(47.8)$ & \\
\hline $\begin{array}{l}\text { 8. The contribution of the COVID- } 19 \text { jab to my health and } \\
\text { well-being is very important. }\end{array}$ & & & & & $<0.001$ \\
\hline agree & $1669(87.4)$ & $1603(89.5)$ & $29(56.9)$ & $37(55.2)$ & \\
\hline uncertain & $201(10.5)$ & $156(8.7)$ & $20(39.2)$ & $25(37.3)$ & \\
\hline disagree & $40(2.1)$ & $33(1.8)$ & $2(3.9)$ & $5(7.5)$ & \\
\hline 9. I can choose whether to get a COVID-19 jab or not. & & & & & $<0.001$ \\
\hline & $1742(91.2)$ & 1647 (91.9) & $46(90.2)$ & 49 (73.1) & \\
\hline uncertain & $68(3.6)$ & $52(2.9)$ & $4(7.8)$ & $12(17.9)$ & \\
\hline disagree & $100(5.2)$ & $93(5.2)$ & $1(2)$ & $6(9)$ & \\
\hline $\begin{array}{l}\text { 10. How the COVID- } 19 \text { jab works to protect my health is a } \\
\text { mystery to me. }\end{array}$ & & & & & $<0.001$ \\
\hline agree & $464(24.3)$ & $383(21.4)$ & $44(86.3)$ & $37(55.2)$ & \\
\hline uncertain & $371(19.4)$ & $344(19.2)$ & $6(11.8)$ & $21(31.3)$ & \\
\hline disagree & $1075(56.3)$ & 1065 (59.4) & $1(2)$ & $9(13.4)$ & \\
\hline 11. I get the COVID-19 jab only because I am required to do so. & & & & & $<0.001$ \\
\hline agree & $262(13.7)$ & $242(13.5)$ & $2(3.9)$ & $18(26.9)$ & \\
\hline uncertain & $139(7.3)$ & $118(6.6)$ & $8(15.7)$ & 13 (19.4) & \\
\hline disagree & $1509(79)$ & $1432(79.9)$ & $41(80.4)$ & $36(53.7)$ & \\
\hline $\begin{array}{l}\text { 12. Getting the COVID-19 jab has a positive influence on my } \\
\text { health. }\end{array}$ & & & & & $<0.001$ \\
\hline agree & $1113(58.3)$ & 1055 (58.9) & $24(47.1)$ & $34(50.7)$ & \\
\hline uncertain & $317(16.6)$ & $266(14.8)$ & $24(47.1)$ & $27(40.3)$ & \\
\hline disagree & $480(25.1)$ & $471(26.3)$ & $3(5.9)$ & $6(9)$ & \\
\hline
\end{tabular}


3.6. Logistic Regression Analysis of Vaccination Attitudes of Willingness and Hesitation (Refusal)

Next, we used logistic regression analysis to find the key factors that affect vaccine acceptance in China. Marital status and health status were predictors of vaccination attitude. Individuals who consciously wore a facemask or believed the protective effect of vaccines were positively associated with the likelihood of vaccine acceptance. All the above are shown in Table 5.

Table 5. Logistic regression analysis of vaccinated attitudes of willingness and hesitation (refusal).

\begin{tabular}{|c|c|c|c|c|c|c|}
\hline & B & S.E. & $p$ & OR & \multicolumn{2}{|c|}{$95 \%$ CI } \\
\hline Place of residence & -0.576 & 0.398 & 0.147 & 0.562 & 0.258 & 1.226 \\
\hline Marital status & -1.023 & 0.499 & $0.040 *$ & 0.360 & 0.135 & 0.956 \\
\hline Educational level & 0.096 & 0.130 & 0.461 & 1.100 & 0.853 & 1.418 \\
\hline Yearly per capita income & 0.075 & 0.209 & 0.718 & 1.078 & 0.716 & 1.623 \\
\hline Health status & -1.026 & 0.422 & $0.015 *$ & 0.359 & 0.157 & 0.820 \\
\hline $\begin{array}{l}\text { Item 1-knowledge of } \\
\text { COVID-19 spreads }\end{array}$ & 0.142 & 0.596 & 0.812 & 1.152 & 0.358 & 3.705 \\
\hline $\begin{array}{l}\text { Item 2-knowledge of } \\
\text { COVID-19 spreads }\end{array}$ & 0.412 & 0.399 & 0.302 & 1.510 & 0.690 & 3.302 \\
\hline $\begin{array}{l}\text { Item 3-knowledge of } \\
\text { COVID-19 spreads }\end{array}$ & -0.374 & 0.413 & 0.365 & 0.688 & 0.306 & 1.545 \\
\hline $\begin{array}{l}\text { Item 4-knowledge of } \\
\text { COVID-19 spreads }\end{array}$ & 0.504 & 0.411 & 0.220 & 1.655 & 0.740 & 3.703 \\
\hline $\begin{array}{l}\text { Item 5-knowledge of } \\
\text { COVID-19 spreads }\end{array}$ & -0.210 & 0.427 & 0.623 & 0.811 & 0.351 & 1.871 \\
\hline $\begin{array}{l}\text { Item 1-knowledge of } \\
\text { COVID-19 symptoms }\end{array}$ & -1.800 & 0.532 & $0.001 *$ & 0.165 & 0.058 & 0.469 \\
\hline $\begin{array}{l}\text { Item 2-knowledge of } \\
\text { COVID-19 symptoms }\end{array}$ & 0.043 & 0.462 & 0.925 & 1.044 & 0.422 & 2.581 \\
\hline $\begin{array}{l}\text { Item 3-knowledge of } \\
\text { COVID-19 symptoms }\end{array}$ & 0.490 & 0.455 & 0.282 & 1.632 & 0.668 & 3.983 \\
\hline $\begin{array}{l}\text { Item 4-knowledge of } \\
\text { COVID-19 symptoms }\end{array}$ & -0.786 & 0.445 & 0.077 & 0.455 & 0.190 & 1.090 \\
\hline $\begin{array}{l}\text { Item 5-knowledge of } \\
\text { COVID-19 symptoms }\end{array}$ & -0.112 & 0.430 & 0.794 & 0.894 & 0.385 & 2.076 \\
\hline $\begin{array}{l}\text { Item 1-knowledge of } \\
\text { COVID-19 vaccination }\end{array}$ & 0.339 & 0.265 & 0.201 & 1.404 & 0.835 & 2.360 \\
\hline $\begin{array}{l}\text { Item 2-knowledge of } \\
\text { COVID-19 vaccination }\end{array}$ & 0.329 & 0.281 & 0.242 & 1.390 & 0.801 & 2.413 \\
\hline $\begin{array}{l}\text { Item 3-knowledge of } \\
\text { COVID-19 vaccination }\end{array}$ & 0.664 & 0.459 & 0.148 & 1.943 & 0.791 & 4.776 \\
\hline 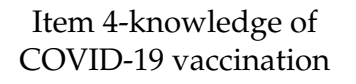 & 0.304 & 0.432 & 0.482 & 1.355 & 0.581 & 3.160 \\
\hline $\begin{array}{l}\text { Item 5-knowledge of } \\
\text { COVID-19 vaccination }\end{array}$ & 0.304 & 0.275 & 0.268 & 1.355 & 0.791 & 2.321 \\
\hline $\begin{array}{l}\text { Item 6-knowledge of } \\
\text { COVID-19 vaccination }\end{array}$ & -1.044 & 0.481 & 0.030 * & 0.352 & 0.137 & 0.903 \\
\hline $\begin{array}{l}\text { Item 7-knowledge of } \\
\text { COVID-19 vaccination }\end{array}$ & -0.348 & 0.201 & 0.083 & 0.706 & 0.477 & 1.046 \\
\hline $\begin{array}{l}\text { Item 8-knowledge of } \\
\text { COVID-19 vaccination }\end{array}$ & 0.602 & 0.373 & 0.107 & 1.826 & 0.879 & 3.795 \\
\hline $\begin{array}{l}\text { Item 9-knowledge of } \\
\text { COVID-19 vaccination }\end{array}$ & -0.381 & 0.285 & 0.181 & 0.683 & 0.391 & 1.194 \\
\hline $\begin{array}{l}\text { Item } 10-\text { knowledge of } \\
\text { COVID-19 vaccination }\end{array}$ & -0.240 & 0.236 & 0.310 & 0.787 & 0.495 & 1.250 \\
\hline $\begin{array}{l}\text { Item } 11-k n o w l e d g e \text { of } \\
\text { COVID-19 vaccination }\end{array}$ & -0.410 & 0.204 & 0.045 * & 0.664 & 0.445 & 0.990 \\
\hline $\begin{array}{l}\text { Item } 12-\text { knowledge of } \\
\text { COVID-19 vaccination }\end{array}$ & -0.208 & 0.209 & 0.320 & 0.812 & 0.539 & 1.224 \\
\hline
\end{tabular}


Table 5. Cont

\begin{tabular}{|c|c|c|c|c|c|c|}
\hline & B & S.E. & $p$ & OR & \multicolumn{2}{|c|}{$95 \%$ CI } \\
\hline $\begin{array}{l}\text { Item 1-preventive measure } \\
\text { of COVID-19 }\end{array}$ & 0.068 & 0.193 & 0.724 & 1.070 & 0.734 & 1.562 \\
\hline $\begin{array}{l}\text { Item 3-preventive measure } \\
\text { of COVID-19 }\end{array}$ & 0.695 & 0.394 & 0.078 & 2.003 & 0.925 & 4.339 \\
\hline $\begin{array}{l}\text { Item 4-preventive measure } \\
\text { of COVID-19 }\end{array}$ & -1.543 & 0.543 & 0.004 * & 0.214 & 0.074 & 0.619 \\
\hline $\begin{array}{l}\text { Item 5-preventive measure } \\
\text { of COVID-19 }\end{array}$ & 1.134 & 0.767 & 0.139 & 3.109 & 0.692 & 13.973 \\
\hline $\begin{array}{l}\text { Item 6-preventive measure } \\
\text { of COVID-19 }\end{array}$ & -0.875 & 0.702 & 0.213 & 0.417 & 0.105 & 1.651 \\
\hline $\begin{array}{l}\text { Item 7-preventive measure } \\
\text { of COVID-19 }\end{array}$ & -0.227 & 0.571 & 0.691 & 0.797 & 0.260 & 2.438 \\
\hline $\begin{array}{l}\text { Item 8-preventive measure } \\
\text { of COVID-19 }\end{array}$ & -0.074 & 0.798 & 0.926 & 0.928 & 0.194 & 4.434 \\
\hline $\begin{array}{l}\text { Item 11-preventive } \\
\text { measure of COVID-19 }\end{array}$ & -0.873 & 0.617 & 0.157 & 0.418 & 0.125 & 1.400 \\
\hline $\begin{array}{l}\text { Item 12-preventive } \\
\text { measure of COVID-19 }\end{array}$ & 3.056 & 0.345 & $<0.001 *$ & 21.237 & 10.794 & 41.785 \\
\hline $\begin{array}{l}\text { Item 13-preventive } \\
\text { measure of COVID-19 }\end{array}$ & 0.527 & 0.811 & 0.515 & 1.694 & 0.346 & 8.297 \\
\hline $\begin{array}{l}\text { Item 14-preventive } \\
\text { measure of COVID-19 }\end{array}$ & -0.962 & 0.816 & 0.238 & 0.382 & 0.077 & 1.892 \\
\hline $\begin{array}{l}\text { Item 15-preventive } \\
\text { measure of COVID-19 }\end{array}$ & -0.481 & 0.339 & 0.156 & 0.618 & 0.318 & 1.201 \\
\hline $\begin{array}{l}\text { Item 16-preventive } \\
\text { measure of COVID-19 }\end{array}$ & -0.102 & 0.493 & 0.836 & 0.903 & 0.344 & 2.371 \\
\hline
\end{tabular}

Notes: *: $p<0.05$. Questions of significant items: Item 1-knowledge of COVID-19 symptoms: Fever and cough; Item 6-knowledge of COVID-19 vaccination: The COVID-19 jab plays an important role in protecting my life and that of others; Item 11-knowledge of COVID-19 vaccination: I get the COVID-19 jab only because I am required to do so; Item 4-preventive measure of COVID-19: I usually put a facemask to protect myself from the risk of infection; Item 12-preventive measure of COVID-19: If there is an available vaccine for the virus, I am willing to get it.

\section{Discussion}

Although the epidemic prevention policies of countries around the world are different, governments of all countries are actively pursuing vaccination projects. More than $100 \mathrm{vac}-$ cine development projects are being conducted and some vaccines have been put into use [16]. A major hindrance facing governments and health organizations is the low vaccination rate relative to requirements of herd immunity. In this study, almost $93 \%$ of Chinese participants surveyed reported intending to be vaccinated. The percentage is similar to previous studies in China $[13,17]$ and higher than some studies from other country [18-23]. A study found relatively high acceptance rates $(>80 \%)$ in Asian countries was related to citizens' high trust in governments [6]. In Asia, the acceptance in Malaysia was 94.3\%, $67.0-93.3 \%$ in Indonesia, and 79.8\% in South Korea, which was relatively higher than most European and American countries [20,24]. Surprisingly, vaccinations are largely accepted in low- and middle-income countries [25]. For instance, about 73\% of adult Egyptians ( $\mathrm{N}=559$ ) would be willing to be vaccinated [15]. On the contrary, the results are quite different in some developed countries. Researchers in England reported 55.8\% participants would accept a COVID-19 vaccine [26]. The acceptance of the vaccine in Italy was only $59 \%$, while France was 58.9-62\% during the pandemic [19,27]. It reported that 50-67\% Americans refused and 25\% said they will never get COVID-19 vaccines [28]. Therefore, it is necessary to identify factors related to vaccine acceptance and hesitancy to implement policy changes and help public health experts determine the conceptual framework and educational activities aimed at raising this awareness in the general population.

Different countries have different influencing factors for vaccine hesitancy. In England, $40.5 \%$ hesitated, related to factors of lower income, lack of belief in safety and effectiveness [26]. While in Egypt, the attitude to vaccines was associated with knowledge about 
COVID-19 [15]. Acceptance of the COVID-19 vaccine in Indonesia is influenced by the effectiveness of the vaccine [24]. It has been demonstrated that vaccine safety and effectiveness strongly influence vaccine acceptance in Australia [29]. In our studies, the results of DrVac-COVID19S suggest that individuals' knowledge about COIVD-19 vaccines is closely related to their vaccination attitude. In China, most citizens comprehend the knowledge of COVID-19 and it was also an important factor for COVID-19 vaccination attitudes, including around transmission, symptoms, and preventive behavior. In the present study, we found that most Chinese had a strong sense of self-management to prevent COVID-19 (washing hands, wearing facemasks regularly, and active reporting, etc.) and more awareness of social participation (following the updates about the spread of virus at home and abroad, etc.). The sense and behavior of self-management was associated with vaccination intention, similarly to the report in Egypt [15]. As expected, individuals with higher educational levels had higher rate of vaccine acceptance, which might be related to their higher knowledge of the pandemic. However, individuals with high educational level also showed more possibility of COVID-19 vaccination hesitation and the phenomenon should be paid more attention. Conversely, older individuals were more skeptical to get vaccinated in our studies, due to them lacking knowledge and worrying about the greater risks of side effects. Although COVID-19 vaccination is free in China, lower income was still associated with vaccine hesitancy and possibly because of these participants have difficulty of accessing correct information about vaccines or the pandemic, and especially the indoctrination of error messages. Therefore, the government and public health experts must take necessary measures to provide more accessible knowledge and encourage positive attitudes to vaccination against COVID-19. An educational framework must also be developed for citizens to advertise the benefits of timely vaccination and actively disseminate accurate information about COVID-19. On other hand, logistic regression showed that the health status is also an important determinant of vaccination attitude. Unsurprisingly, participants with chronic disease status showed more concern on real or perceived risks associated with immunization [30] with a negative effect on vaccination attitude [31,32].

The study has some limitations. Firstly, the conclusions drawn by the cross-sectional survey method may not be so relevant; therefore, further longitudinal research is needed. Secondly, the design of online and offline survey protocol still risks potential selection biases. For example, people who were not accessible in this study are more likely to have a negative attitude towards COVID-19 vaccination. However, our results still confirm and expand results and conclusions from previous related studies. In this study, the types of chronic diseases and the vaccine acceptance of patients with certain diseases are not detailed and comprehensive, which need to be further studied.

\section{Conclusions}

The Chinese participants surveyed in this study had fuller understanding of COVID19 and vaccines, and showed higher acceptance of vaccination. Knowledge of COVID-19, including transmission, symptoms, protective measures, and vaccines themselves, was associated with vaccination attitude. Values, perceived impacts, knowledge, and autonomy, assessed by the scale of DrVac-COVID19S, were also revealed as important determinants to vaccine acceptance. Based on this, government and social workers can take measures from these perspectives to improve the vaccination attitude, so as to increase vaccine immunization rates.

Supplementary Materials: The following are available online at https:/ /www.mdpi.com/article/ 10.3390/ijerph182111192/s1, Table S1: The differences between willing, refused, hesitated attitude among preventive measure of COVID-19, Table S2: The differences between willing, refused, hesitated attitude among knowledge of COVID-19 vaccination. 
Author Contributions: Conceptualization, C.D., R.Z. and Z.G.; methodology, C.D.; software, C.D.; validation, Q.L., T.J.; investigation, C.D., Q.L., T.J.; resources, J.G., J.F. and M.S.; data curation, Q.L. and T.J; writing-original draft preparation, C.D.; writing-review and editing, X.Z. and R.Z.; supervision, R.Z.; project administration, Z.G.; funding acquisition, C.D., X.Z., J.F., J.G. and R.Z. All authors have read and agreed to the published version of the manuscript.

Funding: This work was supported by the National Key Research and Development Program of China [Grant Number 2021YFE0200600], the Postgraduate Research and Practice Innovation Program of Jiangsu Province [Grant Number KYCX21_3106], and the Science and Technology Project of Nantong City, [Grant Number XG202007-1 and XG202007-2 and MSZ21043].

Institutional Review Board Statement: The study was conducted according to the guidelines of the Declaration of Helsinki, and approved by Ethics Committee of the Affiliated Hospital of Nantong University (protocol code 2021-K059-01, June 2021).

Informed Consent Statement: Informed consent was obtained from all subjects involved in the study.

Data Availability Statement: The data presented in this study are available on request from the corresponding author. The data are not publicly available due to further exploration.

Conflicts of Interest: The authors declare no conflict of interest.

\section{References}

1. Wiersinga, W.J.; Rhodes, A.; Cheng, A.C.; Peacock, S.J.; Prescott, H.C. Pathophysiology, Transmission, Diagnosis, and Treatment of Coronavirus Disease 2019 (COVID-19): A Review. JAMA 2020, 324, 782-793. [CrossRef] [PubMed]

2. Zeyaullah, M.; AlShahrani, A.M.; Muzammil, K.; Ahmad, I.; Alam, S.; Khan, W.H.; Ahmad, R. COVID-19 and SARS-CoV-2 Variants: Current Challenges and Health Concern. Front. Genet. 2021, 12, 693916. [CrossRef] [PubMed]

3. Hodgson, S.H.; Mansatta, K.; Mallett, G.; Harris, V.; Emary, K.R.W.; Pollard, A.J. What defines an efficacious COVID-19 vaccine? A review of the challenges assessing the clinical efficacy of vaccines against SARS-CoV-2. Lancet Infect. Dis. 2021, 21, e26-e35. [CrossRef]

4. Anderson, R.M.; Vegvari, C.; Truscott, J.; Collyer, B.S. Challenges in creating herd immunity to SARS-CoV-2 infection by mass vaccination. Lancet 2020, 396, 1614-1616. [CrossRef]

5. Omer, S.B.; Salmon, D.A.; Orenstein, W.A.; de Hart, M.P.; Halsey, N. Vaccine refusal, mandatory immunization, and the risks of vaccine-preventable diseases. N. Engl. J. Med. 2009, 360, 1981-1988. [CrossRef]

6. Lazarus, J.V.; Ratzan, S.C.; Palayew, A.; Gostin, L.O.; Larson, H.J.; Rabin, K.; Kimball, S.; El-Mohandes, A. A global survey of potential acceptance of a COVID-19 vaccine. Nat. Med. 2021, 27, 225-228. [CrossRef]

7. MacDonald, N.E.; the SAGE Working Group on Vaccine Hesitancy. Vaccine hesitancy: Definition, scope and determinants. Vaccine 2015, 33, 4161-4164. [CrossRef]

8. Lin, C.; Tu, P.; Beitsch, L.M. Confidence and Receptivity for COVID-19 Vaccines: A Rapid Systematic Review. Vaccines 2020, 9, 16. [CrossRef]

9. Larson, H.J.; Clarke, R.M.; Jarrett, C.; Eckersberger, E.; Levine, Z.; Schulz, W.S.; Paterson, P. Measuring trust in vaccination: A systematic review. Hum. Vaccines Immunother. 2018, 14, 1599-1609. [CrossRef]

10. Xiao, X.; Wong, R.M. Vaccine hesitancy and perceived behavioral control: A meta-analysis. Vaccine 2020, 38, 5131-5138. [CrossRef]

11. Setbon, M.; Raude, J. Factors in vaccination intention against the pandemic influenza A/H1N1. Eur. J. Public Health 2010, 20, 490-494. [CrossRef]

12. Halpin, C.; Reid, B. Attitudes and beliefs of healthcare workers about influenza vaccination. Nurs. Older People 2019, 31, 32-39. [CrossRef]

13. Wang, J.; Jing, R.; Lai, X.; Zhang, H.; Lyu, Y.; Knoll, M.D.; Fang, H. Acceptance of COVID-19 Vaccination during the COVID-19 Pandemic in China. Vaccines 2020, 8, 482. [CrossRef] [PubMed]

14. Yeh, Y.C.; Chen, I.H.; Ahorsu, D.K.; Ko, N.-Y.; Chen, K.L.; Li, P.-C.; Yen, C.-F.; Lin, C.-Y.; Griffiths, M.D.; Pakpour, A.H. Measurement Invariance of the Drivers of COVID-19 Vaccination Acceptance Scale: Comparison between Taiwanese and Mainland Chinese-Speaking Populations. Vaccines 2021, 9, 297. [CrossRef] [PubMed]

15. Abdelhafiz, A.S.; Mohammed, Z.; Ibrahim, M.E.; Ziady, H.H.; Alorabi, M.; Ayyad, M.; Sultan, E.A. Knowledge, Perceptions, and Attitude of Egyptians Towards the Novel Coronavirus Disease (COVID-19). J. Community Health 2020, 45, 881-890. [CrossRef] [PubMed]

16. Wu, S.; Zhong, G.; Zhang, J.; Shuai, L.; Zhang, Z.; Wen, Z.; Wang, B.; Zhao, Z.; Song, X.; Chen, Y. A single dose of an adenovirus-vectored vaccine provides protection against SARS-CoV-2 challenge. Nat. Commun. 2020, 11, 4081. [CrossRef]

17. Lin, Y.; Hu, Z.; Zhao, Q.; Alias, H.; Danaee, M.; Wong, L.P. Understanding COVID-19 vaccine demand and hesitancy: A nationwide online survey in China. PLoS Negl. Trop. Dis. 2020, 14, e0008961. [CrossRef] [PubMed]

18. Prati, G. Intention to receive a vaccine against SARS-CoV-2 in Italy and its association with trust, worry and beliefs about the origin of the virus. Health Educ. Res. 2020, 35, 505-511. [CrossRef] [PubMed] 
19. Detoc, M.; Bruel, S.; Frappe, P.; Tardy, B.; Botelho-Nevers, E.; Gagneux-Brunon, A. Intention to participate in a COVID-19 vaccine clinical trial and to get vaccinated against COVID-19 in France during the pandemic. Vaccine 2020, 38, 7002-7006. [CrossRef] [PubMed]

20. Wong, L.P.; Alias, H.; Wong, P.F.; Lee, H.Y.; AbuBakar, S. The use of the health belief model to assess predictors of intent to receive the COVID-19 vaccine and willingness to pay. Hum. Vaccines Immunother. 2020, 16, 2204-2214. [CrossRef] [PubMed]

21. Nzaji, M.K.; Ngombe, L.K.; Mwamba, G.N.; Ndala, D.B.B.; Miema, J.M.; Lungoyo, C.L.; Mwimba, B.L.; Bene, A.C.M.; Musenga, E.M. Acceptability of Vaccination Against COVID-19 Among Healthcare Workers in the Democratic Republic of the Congo. Pragmat. Obs. Res. 2020, 11, 103-109. [CrossRef]

22. Reuben, R.C.; Danladi, M.M.A.; Saleh, D.A.; Ejembi, P.E. Knowledge, Attitudes and Practices Towards COVID-19: An Epidemiological Survey in North-Central Nigeria. J. Community Health 2021, 46, 457-470. [CrossRef]

23. Sallam, M.; Dababseh, D.; Eid, H.; Al-Mahzoum, K.; Al-Haidar, A.; Taim, D.; Yaseen, A.; Ababneh, N.A.; Bakri, F.G.; Mahafzah, A. High Rates of COVID-19 Vaccine Hesitancy and Its Association with Conspiracy Beliefs: A Study in Jordan and Kuwait among Other Arab Countries. Vaccines 2021, 9, 42. [CrossRef]

24. Harapan, H.; Wagner, A.L.; Yufika, A.; Winardi, W.; Anwar, S.; Gan, A.K.; Setiawan, A.M.; Rajamoorthy, Y.; Sofyan, H.; Mudatsir, M. Acceptance of a COVID-19 Vaccine in Southeast Asia: A Cross-Sectional Study in Indonesia. Front. Public Health 2020, 8, 381. [CrossRef] [PubMed]

25. Bhopal, S.; Nielsen, M. Vaccine hesitancy in low- and middle-income countries: Potential implications for the COVID-19 response. Arch. Dis. Child. 2021, 106, 113-114. [CrossRef]

26. Bell, S.; Clarke, R.; Mounier-Jack, S.; Walker, J.L.; Paterson, P. Parents' and guardians' views on the acceptability of a future COVID-19 vaccine: A multi-methods study in England. Vaccine 2020, 38, 7789-7798. [CrossRef]

27. Palamenghi, L.; Barello, S.; Boccia, S.; Graffigna, G. Mistrust in biomedical research and vaccine hesitancy: The forefront challenge in the battle against COVID-19 in Italy. Eur. J. Epidemiol. 2020, 35, 785-788. [CrossRef] [PubMed]

28. Guidry, J.P.D.; Laestadius, L.I.; Vraga, E.K.; Miller, C.A.; Perrin, P.B.; Burton, C.W.; Ryan, M.; Fuemmeler, B.F.; Carlyle, K.E. Willingness to get the COVID-19 vaccine with and without emergency use authorization. Am. J. Infect. Control 2021, 49, 137-142. [CrossRef]

29. Borriello, A.; Master, D.; Pellegrini, A.; Rose, J.M. Preferences for a COVID-19 vaccine in Australia. Vaccine 2021, 39, 473-479. [CrossRef]

30. Amanna, I.; Slifka, M.K. Public fear of vaccination: Separating fact from fiction. Viral Immunol. 2005, 18, 307-315. [CrossRef] [PubMed]

31. Bish, A.; Yardley, L.; Nicoll, A.; Michie, S. Factors associated with uptake of vaccination against pandemic influenza: A systematic review. Vaccine 2011, 29, 6472-6484. [CrossRef] [PubMed]

32. Smith, L.E.; Amlot, R.; Weinman, J.; Yiend, J.; Rubin, G.J. A systematic review of factors affecting vaccine uptake in young children. Vaccine 2017, 35, 6059-6069. [CrossRef] [PubMed] 